\title{
Improving the students' writing proficiency through collaborative writing Method
}

Ismail Ismail

STKIP Muhammadiyah Enrekang

\section{Ramadhan}

Universitas Muhammadiyah Makassar

\author{
ARTICLE INFO \\ Article History: \\ Received 14 December 2018 \\ Accepted 15 January 2019
}

\author{
Keywords: \\ Collaborative Writing \\ Method, \\ Descriptive Genre, \\ Improvement, \\ students' proficiency
}

\begin{abstract}
Purposes: The objective of the research was intended to know the improvement of the students' proficiency in writing through collaborative writing method at second year students' of SMA Muhammadiyah Kalosi, Enrekang regency. Methodology: The method of this research is classroom action research consisted of two cycles. The population of this research is all students grade eight at Senior high school; they were 350 students and as a sample of this research consist of ten percent from the population. There were two kinds of data on this research namely qualitative and quantitative. Qualitative data showed that students' interest in writing descriptive because they can write collaboratively, knowledge sharing and critical thinking in teaching and learning process. Quantitative data showed us the improvement from the first up to the last test, the improvement occurred continuously. Findings: The finding of the research was students' improvement in cycle I of content was $17.25 \%$ became $19.37 \%$. The students' improvement of organization was $19.71 \%$ in cycle 1 and it became $20.42 \%$ in cycle 2 . The students' improvement of vocabulary was $13.54 \%$ in cycle 1 and it became $14.09 \%$ in cycle 2 . The students' improvement of language use was $14.71 \%$ in cycle 1 and it became $16.63 \%$ in cycle 2, and the students' improvement of mechanics was $3.42 \%$ in cycle 1 and it became $3.72 \%$ in cycle 2 . Implication: It describes us that there was an improvement on students' proficiency by implementing collaborative writing method.
\end{abstract}

$\triangle$ Corresponding author: Address : STKIP Muhammadiyah Enrekang Email : ismail@ummaspul.ac.id
Published by STKIP Muhammadiyah Enrekang ISSN 2567-0157 (Online) 


\section{INTRODUCTION}

English as one of the languages uses as a tool of sharing ideas on setting information from other people in the world. It has been becoming the international languages that widely used in writing and speaking all over the world. Therefore, the government of Indonesia has been putting English as an essential subject to learn English from elementary school until university.

Communication both in spoken and written is a difference thing. Byrne (1990:1) points out that speaking is just more than the production of sounds while writing is clearly much more than the production of graphic symbols. The symbols have to be arranged, according to certain conventions. The symbols also arranged to be words, from words to sentences, sentences to paragraph, and paragraph to essay.

In Indonesia, English has an important role especially in education. Therefore, English is taught as the first foreign language in all levels of schools and language courses. In school, English has been taught as a local content. Since The Basic Course Outlines of the 2004 Curriculum (2004: 7) in Nurhawaeni states that the objective of learning English at senior high school as a local content is to develop students' communication ability in the context of school. It means that the students are expected to be able to make simple transactional and interpersonal conversation which is potentially needed to communicate in the context of school. Here, the teacher plays important role since he has to be able to set students interest and motivation in learning English in order to develop students' ability to communicate using all the resources they have already acquired to interact with others about their needs and interest.
In this study, the author will focus on teaching writing in Senior high school considering that in learning language writing is the skill that students acquire in first to write something. Writing is important to support learning English especially in enriching vocabulary and gaining a large portion of their education. Therefore the writer considers that writing can be taught at junior high schools.

Schewelger in Fatmawaty (2009: 1) states that writing is one of the hardest things that people do because it requires thinking. He also says that, there are several components in writing that should be mastered in writing such as grammatical structure, vocabulary, coherence, organization, and content. Those components are related to one another in order to produce a good writing. The absence of one of those components will produce poor result of writing.

Due to the importance of writings explained above, the teachers have to develop students' writing ability since it is the first stage they learned English. By developing students' ability to writing well, the teachers develop their students' ability to become more independent learners, as the students will be able to reproduce language accurately and refine their understanding of grammar and develop their own vocabulary. The better students improve their writing ability, the better they reach the achievement in writing Teachers, therefore, should explore a new productive strategy in brightening writing classes in order to encourage students in learning writing skill. They should create interesting and entertaining materials to motivate the students' active responds in doing writing exercise. After the teaching and learning 
process and all the materials are given to the students, there is an expectation that students will make a progress in their study. To know whether the students make some progress in their study, it is useful for teacher to conduct a test or an examination at the end of a program. So the students will be motivated to learn and master the materials which have been taught by the teacher.

There are many reasons for getting students' to write, both in and outside class. Writing gives they more thinking time then they get when they attempt spontaneous conversation. This allows them more opportunity for language processing, that is thinking about the language. When thinking about writing, it is helpful to make a distinction between writing for learning and writing for writing. In the case of the former, writing is used as a practice tool to help students practice and work with language they have been studying. When we are given example, ask a class to write five sentences using by using a given structure, or using five of the new words they have been learning. Writing activity like this are designed to give reinforcement to the students. This is particularly need a mix of visual and kinesthetic activity.

\section{Collaborative Writing}

Collaborative practices are being increasingly advocated in second language classrooms largely in response to the collaborative potential tools. The literature reveals a noticeable increase in interest in collaborative writing ( Elola \& Oskoz, 2010). According to Greg Chaser (2012) argue that collaborative writing projects do not always succeed. This can be due to inexperience, interpersonal conflict, concerns of fairness. Collaboration is defined as people working together to achieve goals (Andersen, 2011:1). It means that the concept of collaborative writing is students' pairs or group work to write formal paper together in order to produce descriptive text together then alone. Each student contributes at each stage of the writing process: brainstorming ideas; gathering and organizing information; and drafting, revising, and editing the writing (Barkley, et al, 2005).

Collaborative writing will improve the students' ability in writing especially descriptive genre. At the time of learning, the weakness students can be strength in learning collaboratively. Ning Setio Wati (2013: 13) states that Collaborative Writing was essentially a social process through which writers looked for areas of shared understanding. Common goal, the differential knowledge, the interacted as a group, and distanced from the text are several social and interactional rules in sharing understanding.

Writing process involve of a series procedure activities for example: prewriting, drafting, responding, revising and editing. This is the stage of writing in order to make writing is easier to do or practice.

Pre-writing is the beginning part or planning that the writer is going to write. This is the most important way in the process of writing. Ning Setio Wati (2013) state that Pre-writing or planning out what is going to be written, is an essential step in the writing process and should account for 70 percent of the writing time forming group or pair of students is the first step by using collaborative writing method in teaching writing, in forming the group or pair, teacher has the authority to decide it with another words teacher facilitate the students in the classroom.

Drafting is a process to develop their ideas into rough draft. The students' is focus on writing draft not in linguistic 
component such as grammar and vocabulary. The students will focus on linguistic component in the next stage because the students will complete the writing in the next stage. In this case, teachers ask students to sit together and compose a piece of writing collaboratively until one writing process cycle is completed (Widodo, 2013).

Responding or giving feedback is primarily intended to see students first or second drafts (Widodo, 2008). It means that when the students receive responding from their peers, they will most probably reflect on whether the feedback or comment needs to be considered. With another words they know their mistake in linguistic and nonlinguistic component by using collaborative writing method. Through this activity can support the students' thinking skill in order to make good writing.

\section{The Advantages of Collaborative Writing Method}

Method is break down to several techniques. Teaching method is a practical realization in learning process. Harmer (2003: 78) states that method is the practical realization of an approach. He also mentioned that method included various procedures and techniques. With another words the writer can conclude that in teaching method the teacher should prepare the procedure and steps that the teacher have to achieve.

Writing is the most important language skill that the students have to master at school. To organize the ideas, information, massage in a proper arrangement is the students' difficulties in writing. The special teaching method that will be applied in this research is collaborative writing method. By implementing this method, the students are expected to be able to improve their writing ability to produce descriptive text.

The author gets the real facts from the situation in learning at the Muhammadiyah High School KalosiEnrekang. Information from English teachers, colleagues, and P2K's research results that class XII holds great potential but they still have difficulty expressing their ideas. Students' abilities are still proportional where there are students who dominate the class of other students tend to be passive. Sources of data indicate that the average value of students is still low (60) under the minimum criteria of success (KKM), which is 65. Based on these problems, the author seeks to improve students' ability to write. This means that researchers have a target of up to 75 to improve students' proficiency in writing through collaborative writing.

This situation opens our eyes to take strategies to maximize their potential. In this case, researchers will find a good way to improve students' writing skills through collaborative writing. Taking into account the contextual background, the formulation of the problem from this study is formulated as follows: (1) how do students improve their writing skills in narrative texts through collaborative writing? (2) How do students improve their writing skills in recount texts through collaborative writing?

\section{METHODOLOGY}

This research was conducted by using classroom action research. Kemmis in Ismawati (2011: 49) state that action research is a form of self-reflective enquiry undertaken by participant in social situation in order to improve the rationality and justice of (a) their own social or educational practices, (b) their understanding of these practice and (c) 
the situation in which the practices carried out. An observation of an activity that appears in class is called action research. This is the reason the term of "action" is used as a method of research.

The research was conducted at SMA Muhammadiyah-Kalosi grade eleven in Enrekang Regency. This research will be done for three months at the academic year 2017/2018. The population of this research consists of six classes, whether each class consists of thirty five students, the populations of this research consist of 210 students. Kothari (2004: 55) states that a sample design is a definite plan for obtaining a sample from a given population. The writer will use purposive sampling technique to get the sample. Arikunto (2005: 136) state that the sample should be $10 \%-100 \%$ from the population. Based on statement above, the writer will take $20 \%$ from the amount of population.

Quantitative and qualitative data were used in this research. Administrating writing test is used to collect the quantitative data. It is used to measure the skill of students in writing. Students will be asked to write the descriptive text with collaborative writing method. Diary note, observation, questionnaire and interview are used to collect qualitative data. There are two cycles of this research procedure that was implemented. Cycle one consist of two meetings include the first meeting as an observation to identify the situation background of teaching learning in the class. Based on the first cycle finding, the researcher decided to conduct the second cycle in order to improve the students' writing skill by revising the procedure of the treatment and motivate the students who get lowest score from cycle I. This cycle II consist of one meeting. The qualitative data will be analyzed from questionnaire, interview sheet and observation sheet.

\section{FINDINGS AND DISCUSSION}

\section{The Students' Improvement in Narrative Text}

The findings of classroom action research deal with the answer of the problem statement which its aim is to improve the students' proficiency in narrative text in writing. It is indicated by the difference between score in the data source, cycle 1 show as the following table:

Table 1: The Students' Improvement of Narrative Text

\begin{tabular}{|c|c|c|c|c|c|c|}
\hline \multirow[t]{2}{*}{ No } & \multirow[t]{2}{*}{ Indicators } & \multicolumn{2}{|c|}{ Data source } & \multicolumn{2}{|c|}{ Cycle 1} & \multirow{2}{*}{$\begin{array}{c}\text { Improvement } \\
\text { (\%) }\end{array}$} \\
\hline & & Mean score & $\%$ & Mean Score & $\%$ & \\
\hline 1. & Orientation & 63.78 & 63.78 & 70.71 & 70.71 & 10.86 \\
\hline 2. & Complication & 62.00 & 62.00 & 67.71 & 67.71 & 9.20 \\
\hline 3. & Resolution & 60.00 & 60.00 & 66.57 & 66.57 & 10.95 \\
\hline & $\sum x$ & 185.78 & 185.78 & 204.99 & 204.99 & 31.01 \\
\hline & $x$ & 61.92 & 61.66 & 68.63 & 67.66 & 10.33 \\
\hline
\end{tabular}

The data in the table 1 shows the students' writing skill score in narrative writing. Before implementing of collaborative writing the data source of orientation is fairly good (63.78\%), after implementing of collaborative writing in cycle 1 , the result is good $(70.71 \%)$ it is greater than the data source. Therefore, the students' improvement is greater in orientation (10.86\%) from data source to cycle 1 . The table above also shows the data source of complication $(62.00 \%)$ is fewer than cycle $1(67.71 \%)$, and it still 
classified as fairly good, although there is improvement of students' writing of complication $(9.20 \%)$ from the data source to cycle 1 . Next, the indicator of narrative writing is resolution. The student score of data source $(60.00 \%)$ is fewer than cycle $1(66.57 \%)$ and it is still classified of fairly good. But there is also a greater improvement of resolution (10.95\%) from data source to cycle 1.
Based on the data of the table 1, the students' score in orientation has achieved of the determine target (70.00\%), but complication and resolution are still lower. It is also still classify in fairly good. Therefore the target can be achieved by being continued in cycle 2 with revision of the plan lesson and teaching material.

\section{The Students' Improvement in Recount Text}

Table 2: The Students' Improvement of Recount Text

\begin{tabular}{|llccccc|}
\hline \multirow{2}{*}{ No } & \multicolumn{1}{c}{ Indicators } & \multicolumn{2}{c}{ Cycle 2 } & \multicolumn{2}{c}{ Cycle 1 } & Improvement \\
\hline 1. & Orientation & 79.14 & 79.14 & 70.71 & 70.71 & $11.92 \%$ \\
\hline 2. & Event & 74.00 & 74.00 & 67.71 & 67.71 & $9.30 \%$ \\
\hline 3. & Reorientation & 76.85 & 76.85 & 66.57 & 66.57 & $15.44 \%$ \\
\hline & $\sum_{x}$ & 229.99 & 229.99 & 204.99 & 204.99 & $36.66 \%$ \\
\hline & $\boldsymbol{X}$ & 76.66 & 76.66 & 68.63 & 67.63 & $12.22 \%$ \\
\hline
\end{tabular}

Table 2 shows the students' writing skill score in recount writing. The score of the data shows the students 'score after the teacher make revising of lesson plan and teaching material. In cycle 2 the teacher revised the teaching material by giving recount serial picture. The result of the students' score in orientation is good $(79.14 \%)$, it is greater than cycle 1 (70.71\%).Therefore the improvement of orientation from cycle 1 to cycle 2 is $11.92 \%$.

The table 2 also shows the score of event in cycle 2 (74.00\%) with classify is good. It is greater than cycle 1 (67.71\%). It means that the improvement of events in cycle 2 is $(9.30 \%)$. Besides the students' writing in re-orientation $(76.85 \%)$ is good than cycle 1 (66.57\%). It is very significant improvement from fairly good become greater with score $15.44 \%$ improvement in cycle 2.

Based on the data of the table 2, the score of the students' in orientation, events, complication, resolution and reorientation are good. There significant improvement with the implementation of collaborative writing in narrative and recount text. Therefore the target (70.00\%) can be achieved in cycle 2 .

The improvement of the students' writing proficiency in narrative and recount text can be identified through collaborative writing is good. It is indicated by the mean score from the data source, cycle 1 and cycle 2 as shows in the table 3 . 
Table 3: The Students' Improvement in Narrative and Recount Writing Proficiency

\begin{tabular}{|c|c|c|c|c|c|c|c|c|}
\hline \multirow{2}{*}{ NO } & \multirow{2}{*}{ VARIABLES } & \multirow{2}{*}{$\begin{array}{c}\text { DATA } \\
\text { SOURCE }\end{array}$} & \multicolumn{2}{|c|}{ CYCLE I } & \multicolumn{2}{|c|}{ CYCLE II } & \multicolumn{2}{|c|}{ IMPROVEMENT (\%) } \\
\hline & & & Score & $\%$ & Score & $\%$ & $\mathrm{DS} \rightarrow \mathrm{C} 1$ & $\mathrm{DS} \rightarrow \mathrm{C} 2$ \\
\hline 1 & Narrative & 61.92 & 68.63 & 68 & 76.66 & 76 & 6.71 & 14.74 \\
\hline 2 & Recount & 61.92 & 68.63 & 68 & 76.66 & 76 & 6.71 & 14.74 \\
\hline & $\sum X$ & 123.84 & 137.26 & 136 & 153.32 & 152 & 13.42 & 29.48 \\
\hline & $\mathrm{X}$ & 61.92 & 68.63 & 68 & 76.66 & 76 & 6.71 & 14.74 \\
\hline
\end{tabular}

The table 3 displays before implementing the collaborative writing is fairly good (61.92\%) in data source. The result in data source of the narrative and recount variable are in related each other. Therefore the mean score of the data source is $61.92 \%$. After implementing the collaborative writing the students' writing improves in cycle 1 is greater than data source even though it is classified still fairly good (68.63\%). The result of the students' improvement in narrative and recount text is $68.63 \%$. But in cycle 2 after the teacher use recount text to measure the student' proficiency in writing, it is revising $(76.66 \%)$ that is higher than cycle 1.

Therefore the improvement of the students' ability in narrative and recount texts from data source to cycle 1 is $6.71 \%$ and the students' improvement from the data source to cycle 2 is $14.74 \%$. It means that the implementation of collaborative in narrative and recount have significant improvement. It is mean that the teacher's target $(70.00 \%)$ can be achieved in cycle 2. The result of the students' improvement can be revealed as the following figure:

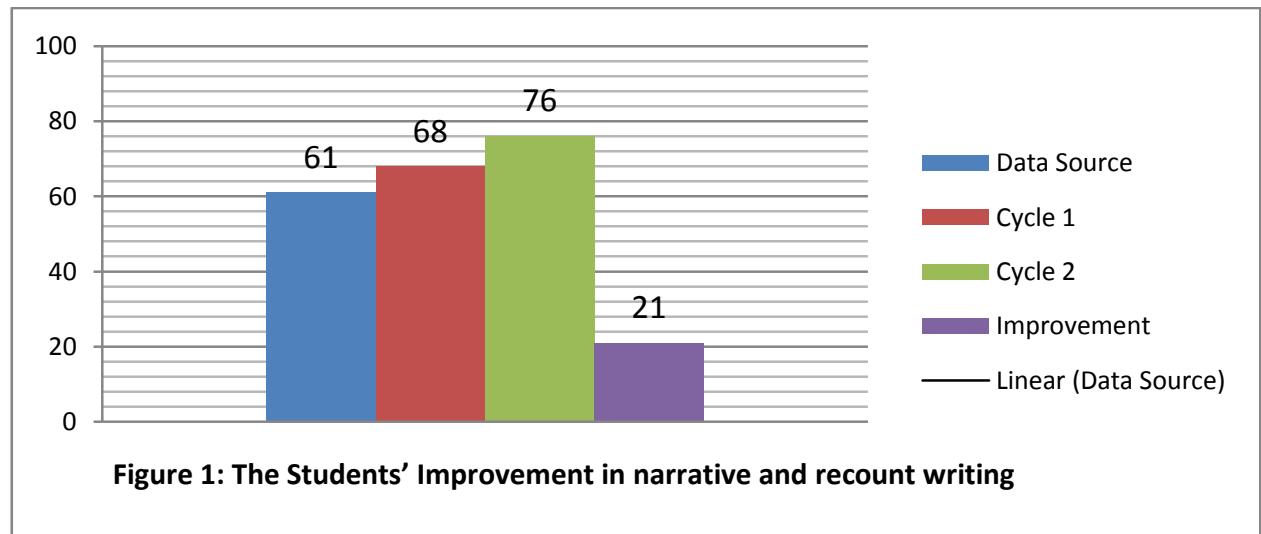

This figure 1 shows the students' improvement in data source, cycle 1 and cycle 2 and also the totality of the students' improvement in collaborative writing. Although the students' achievement in data source to cycle 1 is still fairly good. But in cycle 2 conduct of significant improvement. In implementing of collaborative in recount text the students' improvement in cycle 2 
(76.66\%) is higher than cycle $1(68.63 \%)$. The data source $(61.92 \%)$ is lower than both of cycle 1 and cycle2. Therefore the improvement of the students' writing proficiency in narrative and recount texts is $21.45 \%$.

\section{The Students' Observation in Learning Writing in Cycle 1and Cycle 2}

The following table shows the students' participation in learning narrative and recount texts.

\section{Table 4 The Students' Observation in Learning Writing}

\begin{tabular}{|ccccc|}
\hline Cycles & \multicolumn{4}{c|}{ Participation } \\
& $\begin{array}{c}1^{\text {st }} \\
\text { Meeting } \\
\%\end{array}$ & $\begin{array}{c}2^{\text {nd }} \\
\text { Meeting } \\
\%\end{array}$ & $\begin{array}{c}3^{\text {rd }} \\
\text { Meeting } \\
\%\end{array}$ & $\begin{array}{c}4^{\text {th }} \\
\text { Meeting } \\
\%\end{array}$ \\
\hline Cycle 1 & 57 & 58 & 65 & 66 \\
\hline Cycle 2 & 67 & 70 & 75 & 80 \\
\hline
\end{tabular}

The table 4 describes that the result of students' observation in learning process through collaborative writing in every meeting in cycle 1 to cycle 2 with percentage of first meeting till fourth meeting. The students' participation in learning narrative text at the first meeting is $57 \%$. It has been increasing in the first meeting $(67 \%)$ in the cycle 2 by being implemented of recount text. The second meeting at the cycle 1 (58\%), the students' more interest to learn recount text in the second meeting of cycle 2 (70\%). In the third meeting of cycle 1 (65\%) students' has big interesting in learning narrative text. but there more increasing in third meeting of cycle 2 (75\%) with learning recount text. Even though the last meetings in the cycle 1 , but the students' participation are still under average with (66\%). It has more increasing in the last meeting of cycle 2 (80\%). Where, the students are more interesting to learn recount text in cycle 2. The result of the students' participation shows as the follow graphic:

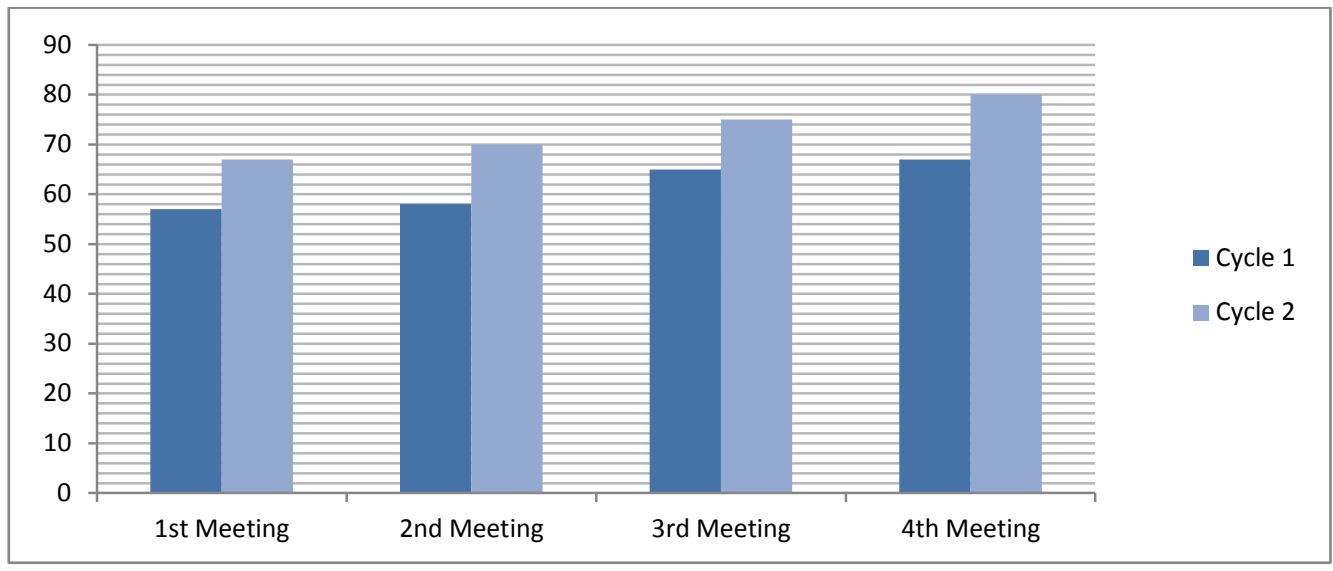

Figure 2: The students' observation in learning writing

The figure 2 illustrations the result of students' observation in learning writing process through collaborative by the students of the second year of SMA Muhammadiyah Kalosi. This figure presented the students' participation during teaching learning process in writing from the $1^{\text {st }}, 2^{\text {nd }}, 3^{\text {rd }}$, and $4^{\text {th }}$ meetings in cycle 1 and cycle 2 . From the graphic it's known that the students' participation in learning writing in cycle 1 is low. Therefore the teacher has revised the lesson plan for improving the students' motivation in learning writing through collaborative writing. 
This graphic presented the students' participation during teaching learning process in writing in cycle 1 (57\%) is lower than cycle $2(67 \%)$ at the $1^{\text {st }}$ meeting. Next, the students' participation in cycle $1(58 \%)$ is lower than cycle 2 (70\%) at the $2^{\text {nd }}$ meeting. And then, the students' participation in cycle $1(65 \%)$ is lower than cycle $2(75 \%)$ at the $3^{\text {rd }}$ meeting. The last meeting in cycle $2(80 \%)$ is higher than the last meeting in cycle 1 (68\%). It is mean that the teacher can improve the students interesting in learning.

\section{DISCUSSIONS}

Table 5: The Result of Students' Orientation Achievement

\begin{tabular}{|c|c|c|c|c|c|c|c|c|c|c|}
\hline \multirow[t]{2}{*}{ Classification } & \multirow[t]{2}{*}{ Score } & \multirow{2}{*}{$\begin{array}{l}\text { Narrative } \\
\text { Indicator }\end{array}$} & \multirow{2}{*}{$\begin{array}{l}\text { Recount } \\
\text { Indicator }\end{array}$} & \multicolumn{3}{|c|}{ Frequency } & \multicolumn{3}{|c|}{ Percentage (\%) } & \multirow[t]{2}{*}{$\mathbf{N}$} \\
\hline & & & & DS & C1 & C2 & DS & C1 & C2 & \\
\hline Excellent & $90-100$ & $\begin{array}{l}\text { Complete to Identify } \\
\text { and set the scene and } \\
\text { introduce the } \\
\text { participant (it answer } \\
\text { the questions: who, } \\
\text { when, and where) }\end{array}$ & $\begin{array}{l}\text { Complete in } \\
\text { introducing the } \\
\text { personal } \\
\text { participation, } \\
\text { place and time }\end{array}$ & 0 & 0 & 0 & 0 & 0 & 0 & \\
\hline Very Good & $80-89$ & $\begin{array}{l}\text { Identify and set the } \\
\text { scene and introduce } \\
\text { the participant enough } \\
\text { (it answer the } \\
\text { questions: who, when, } \\
\text { and where } \\
\text { incomplete) }\end{array}$ & $\begin{array}{l}\text { To introduce the } \\
\text { personal } \\
\text { participation, } \\
\text { place and time } \\
\text { enough. }\end{array}$ & 0 & 0 & 25 & 0 & 0 & 71 & 35 \\
\hline Good & $70-79$ & $\begin{array}{l}\text { Cannot incomplete to } \\
\text { Identify and set the } \\
\text { scene and introduce } \\
\text { the participant. }\end{array}$ & $\begin{array}{l}\text { Cannot } \\
\text { incomplete to in } \\
\text { introduce the } \\
\text { personal } \\
\text { participation, } \\
\text { place and time }\end{array}$ & 6 & 29 & 10 & 18 & 82 & 28 & \\
\hline Fairly Good & $60-69$ & $\begin{array}{l}\text { Not relevant to } \\
\text { Identify and set the } \\
\text { scene and introduce } \\
\text { the participant }\end{array}$ & $\begin{array}{l}\text { Not relevant to } \\
\text { in introducing } \\
\text { the personal } \\
\text { participation, } \\
\text { place and time. }\end{array}$ & 29 & 6 & 0 & 82 & 18 & 0 & \\
\hline Fair & $50-59$ & No answer of concept & $\begin{array}{l}\text { No answer in } \\
\text { introducing. }\end{array}$ & 0 & 0 & 0 & 0 & 0 & 0 & 0 \\
\hline
\end{tabular}

The table 5 indicated that 29 students (82\%) get fairly good and 6 students $(18 \%)$ get good. It improves in cycle 1 where only 6 students (18\%) get fairly good and 29 students (82\%) get
The teacher compared the text result of students in the cycle 1 and cycle 2 which is considered, represent the students' writing improvement. In this part the researcher will compare the generic structure of the narrative are orientation, complication, and resolution. The generic structures of recount are orientation, events and re-orientation.

\section{Orientation}

The data and analysis result of learning narrative and recount in the data source, in cycle 1 , and in cycle 2 in the following table: 


\section{Complication and Events}

Table 6: The Result of Students' Complication and Events Achievement

\begin{tabular}{|c|c|c|c|c|c|c|c|c|c|c|}
\hline \multirow[t]{2}{*}{ Classification } & \multirow[t]{2}{*}{ Score } & \multirow{2}{*}{$\begin{array}{l}\text { Narrative } \\
\text { Indicator }\end{array}$} & \multirow{2}{*}{$\begin{array}{l}\text { Recount } \\
\text { Indicator }\end{array}$} & \multicolumn{3}{|c|}{ Frequency } & \multicolumn{3}{|c|}{ Percentage (\%) } & \multirow[t]{2}{*}{$\mathbf{N}$} \\
\hline & & & & DS & $\mathrm{C} 1$ & $\mathrm{C} 2$ & DS & $\mathrm{C} 1$ & $\mathrm{C} 2$ & \\
\hline Excellent & $90-100$ & $\begin{array}{l}\text { Complete to Identify } \\
\text { the crisis' of problem } \\
\text { arises. When the } \\
\text { problem developed.) }\end{array}$ & $\begin{array}{l}\text { Complete series } \\
\text { of events, } \\
\text { ordered in a } \\
\text { chronological } \\
\text { sequence }\end{array}$ & 0 & 0 & 0 & 0 & 0 & 0 & \\
\hline Very Good & $80-89$ & $\begin{array}{l}\text { Identify the crisis' of } \\
\text { problem arises. When } \\
\text { the problem } \\
\text { developed is enough }\end{array}$ & $\begin{array}{l}\text { To introduce a } \\
\text { series of events, } \\
\text { ordered in a } \\
\text { chronological } \\
\text { sequence is } \\
\text { enough. }\end{array}$ & 0 & 0 & 12 & 0 & 0 & 34 & \\
\hline Good & $70-79$ & $\begin{array}{l}\text { Cannot incomplete to } \\
\text { Identify the crisis' of } \\
\text { problem arises. When } \\
\text { the problem } \\
\text { developed. }\end{array}$ & $\begin{array}{l}\text { Cannot } \\
\text { incomplete a } \\
\text { series of events, } \\
\text { ordered in a } \\
\text { chronological } \\
\text { sequence }\end{array}$ & 0 & 19 & 23 & 0 & 54 & 66 & 35 \\
\hline Fairly Good & $60-69$ & $\begin{array}{l}\text { Not relevant to } \\
\text { Identify the crisis' of } \\
\text { problem arises. When } \\
\text { the problem } \\
\text { developed. }\end{array}$ & $\begin{array}{l}\text { Not relevant a } \\
\text { series of events, } \\
\text { ordered in a } \\
\text { chronological } \\
\text { sequence. }\end{array}$ & 35 & 16 & 0 & 100 & 46 & 0 & \\
\hline Fair & $50-59$ & No answer of problem & $\begin{array}{l}\text { No answer in } \\
\text { events. }\end{array}$ & 0 & 0 & 0 & 0 & 0 & 0 & \\
\hline
\end{tabular}

Based on the table 6, the teacher shows the students' frequency in complication and events. In data source all of the students or 35 students (100\%) get fairly good. It improves in cycle 1 where only 16 students (46\%) get fairly good and 19 students (54\%) get good. Then, in cycle 2 it can be improved there is no students get fairly good, 23 students $(54 \%)$ get good, and there is $12(34 \%)$ get very good.

\section{Resolution and Re-orientation}

The table 7, the teacher shows the students' frequency in resolution in narrative text and re-orientation in recount text. It has same of the students' frequency with complication and events that, in data source all of the students or
35 students (100\%) get fairly good. Then, in cycle 2 it can be improved there is no students get fairly good, and 22 students (62\%) get good, and there is $13(38 \%)$ get very good. 
Table 7: The Result of Students' Resolution and Re-orientation Achievement

\begin{tabular}{|c|c|c|c|c|c|c|c|c|c|c|}
\hline \multirow[t]{2}{*}{ Classification } & \multirow[t]{2}{*}{ Score } & \multirow{2}{*}{$\begin{array}{l}\text { Narrative } \\
\text { Indicator }\end{array}$} & \multirow{2}{*}{$\begin{array}{l}\text { Recount } \\
\text { Indicator }\end{array}$} & \multicolumn{3}{|c|}{ Frequency } & \multicolumn{3}{|c|}{ Percentage (\%) } & \multirow[t]{2}{*}{$\mathbf{N}$} \\
\hline & & & & DS & $\mathrm{C} 1$ & $\mathrm{C} 2$ & DS & $\mathrm{C} 1$ & $\mathrm{C} 2$ & \\
\hline Excellent & $90-100$ & $\begin{array}{l}\text { Complete to find a } \\
\text { way or solution to } \\
\text { solve the problem } \\
\text { Identify the crisis' of } \\
\text { problem arises. }\end{array}$ & $\begin{array}{l}\text { Restated the } \\
\text { writer's } \\
\text { opinion or } \\
\text { personal } \\
\text { comments to } \\
\text { the story. }\end{array}$ & 0 & 0 & 0 & 0 & 0 & 0 & 35 \\
\hline Very Good & $80-89$ & $\begin{array}{l}\text { To find a way or } \\
\text { solution to solve the } \\
\text { problem is enough. }\end{array}$ & $\begin{array}{l}\text { Restated the } \\
\text { writer's } \\
\text { opinion or } \\
\text { personal } \\
\text { comment to } \\
\text { the story is } \\
\text { enough }\end{array}$ & 0 & 0 & 13 & 0 & 0 & 38 & \\
\hline Good & $70-79$ & $\begin{array}{l}\text { Cannot incomplete } \\
\text { to find a way or } \\
\text { solution to solve the } \\
\text { problem. }\end{array}$ & $\begin{array}{l}\text { Cannot } \\
\text { incomplete } \\
\text { restate the } \\
\text { writer's } \\
\text { opinion or } \\
\text { personal } \\
\text { comment to } \\
\text { the story }\end{array}$ & 0 & 12 & 22 & 0 & 34 & 62 & 35 \\
\hline Fairly Good & $60-69$ & $\begin{array}{l}\text { Not relevant to find } \\
\text { a way or solution to } \\
\text { solve the problem }\end{array}$ & $\begin{array}{l}\text { Not relevant } \\
\text { restated the } \\
\text { writer's } \\
\text { opinion or } \\
\text { personal } \\
\text { comment to } \\
\text { the story }\end{array}$ & 35 & 23 & 0 & 100 & 66 & 0 & \\
\hline Fair & $50-59$ & $\begin{array}{l}\text { No answer to solve } \\
\text { the problem }\end{array}$ & $\begin{array}{l}\text { No answer in } \\
\text { giving } \\
\text { comments }\end{array}$ & 0 & 0 & 0 & 0 & 0 & 0 & \\
\hline
\end{tabular}

Base on the research, the teacher divided the variable in narrative and recount. In the cycle 1 of this classroom action research the teacher get the different result of orientation in narrative text and recount text. Most of the students 'have been difficult to make a specific characteristic of the actor and actress. But, in orientation of the recount that the students' have been easier in find the characteristic of actor and actress by helping words and accordance in the picture. Narrative and recount text have a similarity indicator that the students' should find out the character of the actor, where, and when the story happened.
The students' improvement in cycle 1 to cycle 2 is good. Most of the students' were difficult in cycle 1 to find out the complication of the story. It has different with indicator of recount text. Where the students' should find the problem in complication of narrative and events in recount text. In cycle 2 they find easy way in recount serial picture, where they can make an event sequence with helping picture. It has different with narrative that they cannot find a clear problem in the story. But it has a similarity in find the generic structure of complication and event, that the students' should find the important problem in the story. 
Resolution and reorientation are the similarity generics of the narrative and recount. Where the students' should find the solving of the problem in narrative text. It also conducts of the end story. It means that the end of the story.

The improvement of the students' proficiency to write good paragraphs through collaborative writing is effective in classroom action research. Where, the teacher finds in the improving from data source to cycle 1 and cycle 2 are good. Most of the student' got around 60-65 in data source of generic structure of narrative and recount text. It means that it is far from the target, but after implemented the students could get the indicator score that is 70 in cycle 2 . The researcher taught about the narrative paragraph in the cycle 1 through collaborative writing in the classroom action research. The researcher found that the students still difficult to write. They are still confused to find the generic structure of narrative text that what they want to write in the paper.

The difficulty of the students in writing had been analyzed, so the researcher had to think the solution of the problem. So, the researcher decided to do the cycle 2 by doing revision in the lesson plan which prepared in revision planning of cycle 2 .

The result of revision planning to resolve the students' difficulty in setting idea was in the free writing activity the researcher changed the method free writing become picture series in recount text. Besides changing the method in free writing the researcher also change the teaching material of narrative text to be recount text. It was done to avoid the repetition in learning and teaching process.

The findings display that there was a good response from the students about the implementation revision planning of collaborative writing. Where, the students' mean score could get the target score that is 70 .

\section{CONCLUSION}

Based on the result of the implementation of cooperative learning through collaborative writing method at SMA Muhammadiyah Kalosi-Enrekang, the conclusion is students' writing skill improved from the first up to the last test. The researcher can make conclusion as the following: (1) Collaborative writing method is significant to improve the students' writing to identify of the orientation, complication, and resolution of the narrative writing skill at SMA Muhammadiyah Kalosi-Enrekang. (2) Collaborative writing method also improves the students' ability in writing specially in identifying of the orientation, events and re-orientation in writing recount text. The results of research indicated that the students get increasing value from the cycle I and cycle II. It was accordance with the successfully criteria that has been gotten in planning, action, observation and reflection. (3) The students are active in learning English subject. It can indicate of the students' improvement in learning narrative and recount texts. It is also analyzed from the students' activity observation sheet as show at the attachment. The students' response toward the collaborative writing most positively. The students' like to learn English subject with group because they can more actively. The teacher does not give speech method that can make the students bored.

\section{Implication}

The result on this research shows that collaborative writing method improves the students' achievement on writing descriptive. Suggestions are offered to English teachers, it is better to 
use collaborative writing method in teaching writing because through applying this treatment students can work collaboratively, share their knowledge and assisting each student for their problems. For the students, writing is not an easy skill to master like another skill. Exercise regularly and make writing as a habit is the key to master this skill. For other researcher, it is realized that the high percentage who pass this test is $70 \%$ it means that lack of reflection was faced by the writer, it suggested to the next researcher who are interested on this field and conduct a research can create an innovation to collaborative writing method. Another researcher can make a research by using collaborative writing method as a treatment on other genre.

\section{REFERENCES}

[1] Agoestyowati, Redjeki. 2007. 102 English Games. Jakarta: PT Gramedia Pustaka Utama.

[2] Azis, Astuti. 2004. Meningkatkan kemampuan paragraph deskriftif dengan penggunaan medi kartu pos pada siswa kelas III SMPN 4 Sungguminasa. Laporan PTK.

[3] Dalle, Basri. 2010. Fundamentals of Research Methodology. Makassar: Universitas Muhammadiyah Makassar

[4] Damayanti, Irma. 2009. Increasing the students' writing skill through dyadic essay confrontation technique. Skripsi. Makassar: Fakultas Keguruan dan Ilmu Pendidikan Universitas Muhammmadiyah.

[5] Enrlich, Eugene. 1997. Punctuation, capitalization, and Spelling. New York: M Grow Hill book.
[6] Fatmawati.2009. Increasing the students' writing proficiency through picture series Makassar: thesis of Unismuh Makassar.

[7] Fisher, Nan. 2002. Collaborative writing. Retrieved from

[8] (http:// www. Pagawise. Com / diselaimer. htm) on May 142010

[9] Farkas, David .What Is Collaborative Writing .Retrieved from (http:// en. wikipedia.org / wiki / collaborative_writing) on June 2010.

[10] Gairns, Ruth and Redman, Stuart. 1986. Working with word. New York: Cambridge University

[11] Hammer, Jeremy. 1991. The Practice of English Language teaching. New York: Cambridge University.

[12] Mustakim, M., \& Ismail, I. (2017). PENINGKATAN KETERAMPILAN MENULIS AKADEMIK BAHASA INGGRIS MELALUI TEKNIK PENGAJARAN DICTOGLOSS. Edumaspul - Jurnal Pendidikan, 1(2), 80-91. https://doi.org/10.33487/edumas pul.v1i2.42

[13] Ismail, I., Jabri, U., Rahmat, R., \& Musdalifah, M. (2017, November). Rubrics-Based Assessment as a Teaching Strategy of Writing Journal for Novice Authors. In INTERNATIONAL CONFERENCE ON EDUCATION (Vol. 1, No. 01).

[14] Kammer Tuahman Sipayung. (2016). The implementation of collaborative writing method to improve students' writing of descriptive Genre at SMP Negeri 3 Percut Sei Tuan on Grade VIII at the Academic Year 2015/2016. JURNAL Suluh Pendidikan FKIPUHN, vol. 3 (1) 88-99. 
[15] Koller, Max. 2009. English Teaching Forum Magazine. USA: United States Departement..

[16] L.A.Dumaris, 1998. Writing in English.Jakarta: Depdikbud.

[17] Louth Richard and Carole Mcallister. Research of Collaborative Writing Techniques on Freshman Writing and Attitude. Southeastern Louisiana University retrieved from (http:// wapedia. Mobi/ en / collaborative_method) on June 2010

[18] Nurhawaeni. 2004. Developing the students' writing skill using magazine picture to the third year. Makassar: Thesis Unismuh

[19] Oshima, Alice and Ann Hogue. 1997. Introduction to Academic
Writing. London and New York: Longman Group UK Limited.

[20] Ramelan. 1993. English Language. The University of Tennessee at Chattanooga. All rights reserved. (http:// www. English language.htm) on May 14,2010

[21] Raynal. 2010. Characteristic of Recount Text. (http:// www.raynal.files.wordpress.com.2 010.gif) on May 14, 2010

[22] Raynal and David. 2010. Characteristic of Narrative Text. (http:// on May 14,2010

[23] Thomas, Jenny.1995.Meaning in interaction: an introduction to Pragmatic. United State of America: Addison Wesley Longman Inc. 